\title{
Ile administracji w ochronie zdrowia? S. Sikorski, Administracja ochrony zdrowia w Polsce - między świadczeniem a reglamentacja
}

\author{
Adam Ryś ${ }^{1}$
}

Monografie z zakresu prawa administracyjnego wyróżniają się szczególną cechą, rzadziej spotykaną w publikacjach dotyczących innych gałęzi prawa. Zauważalne jest bowiem w nich to, że zazwyczaj znaczna ich część poświęcona jest rozważaniom pojęciowym, których celem jest próba uporządkowania pojęć używanych w prawie administracyjnym i naukach o administracji publicznej w sposób niekiedy zbyt swobodny, by nie powiedzieć dowolny.

Niewątpliwą zaletą pracy Sebastiana Sikorskiego pt. Administracja ochrony zdrowia w Polsce - między świadczeniem a reglamentacją (Warszawa: Wolters Kluwer, 2021) jest próba uporządkowania bardzo rozległej siatki pojęciowej. Dla każdego prawnika, nawet jeśli nie jest on administratywistą (a może w szczególności właśnie dla przedstawicieli innych gałęzi), dostrzegalny być musi ogromny wysiłek, jaki niewątpliwe towarzyszy opracowaniu samego pojęcia ,,administracja publiczna”. Stąd lektura pierwszego rozdziału pracy stanowić może autonomiczne opracowanie jednego z węzłowych problemów w doktrynie prawa administracyjnego. Problem ten sprowadza się do pytania, jak poprawnie używać nazw poszczególnych funkcji administracji publicznej.

Wychodząc od porządkującego podziału działań administracji na administrację władczą (reglamentacyjną) oraz świadczącą, wypada zgodzić się z założeniem - jak się zdaje będącym motywem przewodnim całej pracy że wobec wyzwań związanych z prawną regulacją jednego z najdroższych, zdaniem Autora, obszarów aktywności państwa - ochrony zdrowia (por. s. 117) niezbędne jest opracowanie gruntownej teoretycznej analizy administracji publicznej w ochronie zdrowia z wykorzystaniem kategorii „funkcji administracji” jako narzędzia badawczego.

Można natomiast postawić pytanie, na ile zasadne jest przywołanie znacznej liczby poglądów przedstawicieli nauk prawnych, nauk o administracji, nauk społecznych, a także poglądów teoretyków prawa, a nawet klasycznych już dzisiaj filozofów. W przypadku tych ostatnich uzasadnione może to być okolicznością, że są oni twórcami określonych pojęć, wykorzystanych przez naukę prawa administracyjnego. Samo przytaczanie rozmaitych poglądów wypada zatem ocenić pozytywnie, jednak przy lekturze nasuwa się nieodparte wrażenie, że niekiedy trudno jest odczytać poglądy samego autora na temat poszczególnych tez przytaczanych za innymi przedstawicielami nauk o zdrowiu z jednej strony, a doktryny prawniczej z drugiej.

W pracy widoczny jest niewątpliwy wpływ perspektywy administracyjnoprawnej, czemu nie można się dziwić, bo to praca lokowana w tym obszarze teoretycznym. W konsekwencji jednak nieco na drugi plan schodzą kwestie uwarunkowań politycznych i gospodarczych. Reformy sektora ochrony zdrowia przedstawione są w sposób rzetelny z punktu widzenia ich prawniczej treści. Troska o rzetelność w przedstawianiu referowanych poglądów nadaje wywodom w dużej mierze charakter sprawozdawczy. Można zatem powiedzieć, że Autor z powodzeniem zachowuje bezstronność, jednak dla czytelników będących praktykami prawa albo osobami angażującymi się w próby reformowania systemu zdrowotnego może być to odczytane jako brak postulatów de lege ferenda, a więc unikanie przez Autora zajęcia własnego stanowiska w przedstawianych sprawach.

Zgodnie z jasną deklaracją Autora, że praca ma charakter teoretyczny, w takiej właśnie perspektywie przedstawił on - problematyzując badany obszar - kwestię możliwych rozwiązań prawnych w systemie zdrowotnym. Natomiast gdy spojrzeć na recenzowaną pracę od strony praktycznej, a więc kwestii poruszanych de lege lata, to nie da się powiedzieć, że służyć może ona praktykom na co dzień stosującym prawo, a więc urzędnikom, sędziom, adwokatom czy radcom prawnym. Jako otwarte pozostawiam pytanie, na ile służby prawne obsługujące podmioty lecznicze bezpośrednio

Autor jest radcą prawnym, prowadzącym kancelarię w Krakowie. 
zaangażowane w świadczenie usług zdrowotnych będą mogły wykorzystywać tę książkę w codziennej pracy.

Nie mam natomiast wątpliwości, że recenzowana publikacja będzie bardzo cennym opracowaniem dla osób, których zawodowym (praktycznym) lub akademickim (naukowym) celem są takie przedsięwzięcia, jak przygotowywanie założeń do projektów określonych aktów prawnych, w tym ustaw i rozporządzeń. Lektura monografii ułatwi bowiem osobom zajmującym się ochroną zdrowia z perspektywy prawnej uporządkowanie pojęć, poznanie genezy poszczególnych instytucji ochrony zdrowia w Polsce (zarówno w rozumieniu prawnym, jak również jako elementów administracji publicznej). Świadomość zakorzenienia różnych instytucji prawnych w przeszłości, tak w sensie tradycji prawnej, jak i wpisania ich w społeczny i organizacyjny kontekst może pozwolić na podejmowanie bardziej racjonalnych interwencji. W trwającej praktyce nierzadko bowiem można odnieść wrażenie, że sporo zmian $\mathrm{w}$ systemie prawa polega na zastępowaniu wybranych regulacji innymi w sposób sprowadzający się do zmian powierzchownych, to znaczy zmian nazewnictwa. Tymczasem konfrontacja $\mathrm{z}$ doświadczeniem pracowników sektora ochrony zdrowia od kadry zarządzającej w dół utwierdza w przekonaniu, że za zmianami ustawodawczymi często nie idą realne zmiany w sposobie wykonywania zadań przez daną instytucję. Zmieniają się nazwy stanowisk, wewnętrzne struktury jednostek są przekształcane, co skutkuje wymianą kadry kierowniczej, jednak zasada działania pozostaje taka sama - ze wszystkim jej zaletami i wadami.

Lektura monografii przez osoby próbujące reformować sektor ochrony zdrowia miałaby zatem niewątpliwe spory walor edukacyjny. Gdyby politycy byli skłonni pogłębić swoją wiedzę na temat funkcjonowania prawnych mechanizmów wykorzystywanych w regulowaniu sektora zdrowotnego, miałoby to bardzo pozytywny wpływ na jakość debaty, ale i wdrażanych finalnie rozstrzygnięć. Jednak w procesie edukacji z uwagi na teoretyczny charakter opracowania nie można zalecać powstrzymania się od dalszych lektur. Pomimo przytoczenia przez autora pewnej liczby organizacyjnych i prawnych konkretów, w tym pewnej liczby orzeczeń, nie dowiemy się z pracy, jak funkcjonuje w polskim porządku prawnym administracja ochrony zdrowia. I pamiętać należy, że mechanizmy prawne są tylko jednym z narzędzi, jakie można - i należy - wykorzystać w usprawnianiu działania systemu zdrowotnego. Każda próba istotnej zmiany legislacyjnej w tym zakresie winna być poprzedzona gruntownym rozpoznaniem merytorycznym i formalnym przedmiotu ingerencji prawnej. Recenzowaną monografię można potraktować jako dobry opis poszczególnych części szerokiego obszaru administracji ochrony zdrowia, będącą swoistą „mapą drogową” oraz zachętą do dalszych studiów i analiz. 